\title{
Flight Costs and Fuel Composition of a Bird Migrating in a Wind Tunnel
}

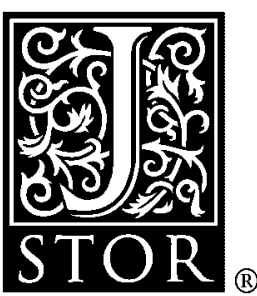

\author{
Marcel Klaassen; Anders Kvist; Åke Lindström \\ The Condor, Vol. 102, No. 2. (May, 2000), pp. 444-451.
}

Stable URL:

http://links.jstor.org/sici?sici=0010-5422\%28200005\%29102\%3A2\%3C444\%3AFCAFCO\%3E2.0.CO\%3B2-\%23

The Condor is currently published by Cooper Ornithological Society.

Your use of the JSTOR archive indicates your acceptance of JSTOR's Terms and Conditions of Use, available at

http://www.jstor.org/about/terms.html. JSTOR's Terms and Conditions of Use provides, in part, that unless you have obtained prior permission, you may not download an entire issue of a journal or multiple copies of articles, and you may use content in the JSTOR archive only for your personal, non-commercial use.

Please contact the publisher regarding any further use of this work. Publisher contact information may be obtained at http://www.jstor.org/journals/cooper.html.

Each copy of any part of a JSTOR transmission must contain the same copyright notice that appears on the screen or printed page of such transmission.

JSTOR is an independent not-for-profit organization dedicated to and preserving a digital archive of scholarly journals. For more information regarding JSTOR, please contact support@jstor.org. 
Cantos, F. J., and J. L. Telleria. 1994. Stopover site fidelity of four migrant warblers in the Iberian Peninsula. J. Avian Biol. 25:131-134.

Cramp, S. [ED.] 1992. The birds of the Western Palearctic. Vol. 6. Warblers. Oxford Univ. Press, Oxford.

CuAdRADO, M. 1992. Year to year recurrence and site fidelity of Blackcaps Sylvia atricapilla and Robins Erithacus rubecula in a Mediterranean wintering area. Ringing and Migr. 13:36-42.

Dement'Ev, G. P., AND N. A. GladKov. 1968. Birds of the Soviet Union. Vol. 6. Israel Program for Scientific Translations, Jerusalem.

DowsetT-Lamaire, F, AND R. J. DowsetT. 1987. European Reed and Marsh Warblers in Africa: migration patterns, moult and habitat. Ostrich 58:6585.

Hovel, H. 1987. Check-list of the birds of Israel. Soc. Protec. Nature Israel, Tel Aviv.

LoNG, R. 1975. Mortality of Reed Warblers in Jersey. Ringing and Migr. 1:28-32.

Merom, K., R. MCCleERY, AND Y. Yom-Tov. 1999. Age-related changes in wing-length and body mass in Reed Warbler Acrocephalus scirpaceus and Clamorous Reed Warbler A. stentoreus. Bird Study 46:249-255.

Moreau, R. E. 1972. The Palearctic-African bird migration systems. Academic Press, London.

Morris, S. R., D. W. Holmes, AND M. E. Richmond 1996. A ten-year study of stopover patterns of migratory passerines during fall migration on Appledore Island, Maine. Condor 98:395-409.

OtAhaL, C. D. 1995. Sexual differences in Wilson's Warbler migration. J. Field Ornithol. 66:60-69.
PARrish, J. D. 1997. Patterns of frugivory and energetic condition in Nearctic landbirds during autumn migration. Condor 99:681-697.

PEARSON, D. J. 1972. The wintering and migration of Palearctic passerines at Kampala, southern Uganda. Ibis 114:43-60.

Rimmer, C. C., AND C. H. Darmstadt. 1996. Nonbreeding site fidelity in Northern Shrikes. J. Field Ornithol. 67:360-366.

SoKolov, L. V. 1988. Philopatry of migratory birds. Ornithologiya 23:11-25.

Winker, K., D. W. WARner, AND A. R. Weisbrod. 1991. Unprecedented stopover site fidelity in a Tennessee Warbler. Wilson Bull. 103:512-514.

Winker, K., D. W. WARner, AND A. R. Weisbrod. 1992. Daily mass gains among woodland migrants at an island stopover site. Auk 109:853-862.

Yom-Tov, Y. 1993. The importance of stopover sites in deserts for Palearctic migratory birds. Israel $\mathrm{J}$. Zool. 39:271-273.

Yom-Tov, Y., AND R. BEN-ShahAR. 1995. Seasonal body mass and habitat selection of some migratory passerines occurring in Israel. Israel J. Zool. 41:443-454.

Yom-Tov, Y., AND M. Mendelssohn. 1988. Changes in the distribution and abundance of vertebrates in Israel during the 20th century, p. 515-547. In Y. Yom-Tov and E. Tchernov [EDS.], The zoogeography of Israel. Dr. W. Junk, Dordrecht.

YonG, W., AND D. M. FINCH. 1997. Migration of the Willow Flycatcher along the middle Rio Grande. Wilson Bull. 109:253-268.

\title{
FLIGHT COSTS AND FUEL COMPOSITION OF A BIRD MIGRATING IN A WIND TUNNEL
}

\author{
MARCEL KLAASSEN \\ Max-Planck-Institut für Verhaltensphysiologie, D-82346 Andechs, Germany, and \\ Netherlands Institute of Ecology, Centre for Limnology, P.O. Box 1299, 3600BG Maarssen, \\ The Netherlands, e-mail: klaassen@cl.nioo.knaw.nl \\ ANDERS KVIST AND ÅKE LINDSTRÖM \\ Department of Animal Ecology, Lund University, Ecology Building, S-223 62 Lund, Sweden
}

Abstract. We studied the energy and protein balance of a Thrush Nightingale Luscinia luscinia, a small long-distance migrant, during repeated 12-hr long flights in a wind tunnel and during subsequent twoday fueling periods. From the energy budgets we es-

\footnotetext{
${ }^{1}$ Received 13 May 1999. Accepted 12 January 2000 .
}

timated the power requirements for migratory flight in this $26 \mathrm{~g}$ bird at 1.91 Watts. This is low compared to flight cost estimates in birds of similar mass and with similar wing shape. This suggests that power requirements for migratory flight are lower than the power requirements for nonmigratory flight. From excreta production during flight, and nitrogen and energy balance during subsequent fueling, the dry protein proportion of stores was estimated to be around $10 \%$. A 
net catabolism of protein during migratory flight along with that of fat may reflect a physiologically inevitable process, a means of providing extra water to counteract dehydration, a production of uric acid for anti-oxidative purposes, and adaptive changes in the size of flight muscles and digestive organs in the exercising animal.

Key words: body stores, energy budget, flight costs, Luscinia luscinia, migration, protein balance, Thrush Nightingale.

Many birds migrate huge distances between breeding and wintering areas. Estimates of the power requirements for migratory flights and the composition of the body stores that fuel these flights are the prime physiological parameters required for proper understanding of ecological and evolutionary constraints acting on migratory birds. Aerodynamic models (Pennycuick 1989) are frequently applied to estimate flight power and flight range for migratory birds. Yet, these models require testing and their validity is under continuous discussion (Pennycuick et al. 1996, Pennycuick 1998). Although power requirements for flight have been measured in many different species of birds (Masman and Klaassen 1987, Norberg 1996), the power requirement for long-distance migratory flights has never been measured. Therefore, calculations on flight duration and range for migrating birds are still handicapped by an insufficient scientific basis.

For a long time it was thought that birds exclusively use fat to fuel their migratory flights (Odum et al. 1964). This concept makes sense, because fat is by far the most energy-dense substrate available to birds (Blaxter 1989). Accordingly, the energy cost of transporting fuel could be kept to a minimum (Pennycuick 1975). However, recent compositional analyses of carcasses have shown that up to $9-15 \%$ of the body mass increase of migrants prior to migration consists of (dry) protein (Lindström and Piersma 1993, Klaassen and Biebach 1994). Studies of blood metabolites of birds trapped during active migration (Jenni-Eiermann and Jenni 1991), and of energy and nitrogen balance experiments during starvation and subsequent refueling of captive birds in migratory disposition (Klaassen and Biebach 1994, Klaassen et al. 1997), also indicate that protein is lost during the migratory act. It has been suggested that a protein loss during flight may be due to a physiologically inevitable process (Dohm 1986, Jenni and Jenni-Eiermann 1998), is a means of providing extra water to counteract dehydration (Klaassen 1996), and may reflect adaptive changes in the size of flight muscles and digestive organs (Piersma and Lindström 1997). However, hardly any detailed information exists on birds studied during and after long migratory flights.

We trained a single, juvenile, hand-raised Thrush Nightingale Luscinia luscinia to fly for extended periods in a wind tunnel. The Thrush Nightingale is a long-distance migrant species that breeds in northeastern Europe and winters in southeastern Africa (Cramp 1985). Detailed data on metabolism during migratory fuelling of Thrush Nightingales are available for comparison (Klaassen and Biebach 1994, Klaassen et al. 1997). The bird flew a total of $176 \mathrm{hr}$ at $10 \mathrm{~m} \mathrm{sec}^{-1}$ in flights lasting up to $16 \mathrm{hr}$ and thus traveled an air distance of $6,300 \mathrm{~km}$, which is comparable to the distance between the species' breeding and wintering area. The impacts of these long flights on the basal metabolic and intake rate of the bird during recovery are presented in Lindström et al. (1999). Here we present an estimate of the bird's flight power using an energy balance method (Masman and Klaassen 1987), which is accurate and allows the bird to fly freely without any measuring devices attached. The composition of the body stores to fuel the flight, in terms of fat, protein, and water, was estimated by compiling energy and nitrogen balances during the flights and the following recovery periods in which the bird regained lost body stores. We found a significant protein turnover during this simulated migratory flight and a flight power that is lower than that measured in nonmigrants of comparable size and wing-shape.

\section{METHODS}

\section{BIRD, HOUSING, AND TRAINING}

Our focal bird was a hand-tame juvenile Thrush Nightingale. For the origin of the bird and housing conditions prior to and in-between the experimental trials, see Lindström et al. (1999). Technical details of the wind tunnel, specially designed for studies of bird flight, are presented by Pennycuick et al. (1997). The flight training began by having the bird sit on a stick in the test section, thereafter it was released in the air flow by removing the stick. By gradually increasing the duration between the moment the stick was removed and the moment the stick was re-offered, the bird soon flew for extended periods. After several successful flights lasting $0.5-2 \mathrm{hr}$, we decided to try to have the bird fly for a number of 12-hr periods, allowing comparison with migratory flights in free-living Thrush Nightingales. Initially, we intended to have the bird fly at night (the species is a night migrant), but during early attempts the bird did not fly properly under the dusk-like conditions we offered.

\section{FLIGHTS}

The principal objective of our study was to have an unrestrained bird fly in the wind tunnel for a long period, resulting in a considerable loss of mass. During the flight, dropping collection (see below) would monitor protein content of the body stores used to fuel migratory flight. During the subsequent period of recovery, the energy and protein balance would be monitored by a combination of indirect calorimetry and feeding balance (see below). For the recovery period we assumed that the bird restored what it had lost during the flight (Masman and Klaassen 1987). The energy and protein balance during the recovery would thus provide insight into the composition of the substrate catabolized during flight. Finally, the energy balance would allow the calculation of the energy requirements for flight (Masman and Klaassen 1987).

Each trial (cycle of mass loss and recovery; Fig. 1) lasted three full days, commencing with a 12-hr flight session followed by $12 \mathrm{hr}$ of night rest and $48 \mathrm{hr}$ of recovery. Seven trials were conducted between 18 September and 10 November 1995 (always running from Monday morning until Thursday morning). Food was removed from the bird at least $12 \mathrm{hr}$ prior to the 


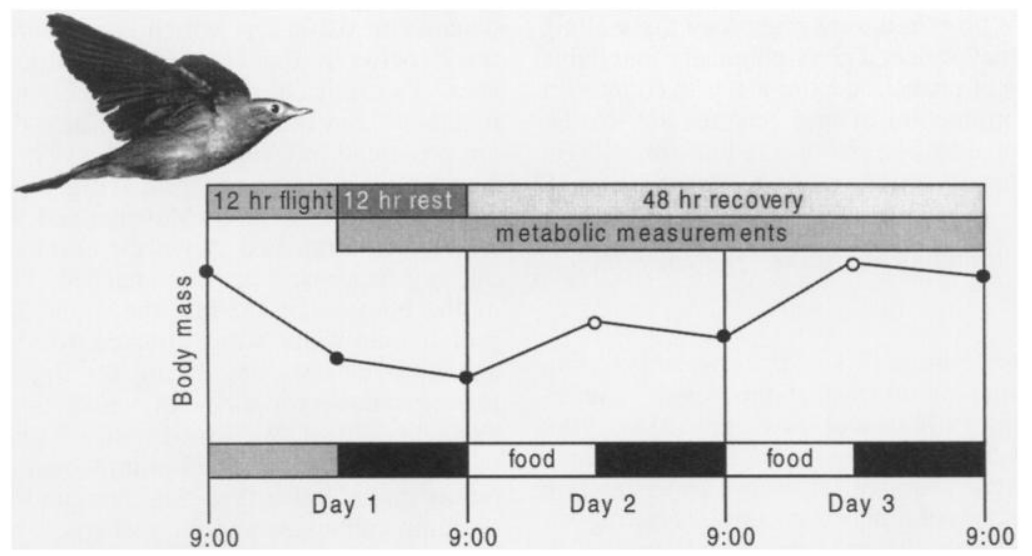

FIGURE 1. Outline of the 3-day experimental trial with a Thrush Nightingale that was initialized by a 12-hr flight in a wind tunnel followed by a 12-hr period of night rest and concluded by a 48-hr recovery period. Indicated is the period during which the bird was in the metabolic chamber for the monitoring of its metabolism, the periods of food availability, and when the lights were on and off (black bars at bottom). A typical pattern of body mass change during the 3-day trial is depicted with filled circles marking actual body mass measurements and open circles marking estimated evening body masses (when the bird was not weighed).

flight, ensuring that the bird was post-absorptive at the start of the trial (Klaassen and Biebach 1994). This procedure guaranteed that the bird used its body stores to fuel its flight. Starting migration with an empty stomach is a regular phenomenon in migrating birds. Wind speed (and thus flight speed) was set at $10 \mathrm{~m}$ $\mathrm{sec}^{-1}$, which was estimated to be close to the predicted maximum range speed of the bird (Pennycuick 1989); it also seemed to be the most comfortable speed for the bird to fly at. Body mass is expected to influence flight power (Pennycuick 1989). We therefore fed the bird during the days preceding each trial in such a way that body mass at the start was similar for all trials.

After weighing the bird to the nearest $0.01 \mathrm{~g}$, the experimental trial started with the 12-hr flight at 09:00. Every second hour the bird was taken out of the wind-tunnel test section for weighing, which took 1-3 min. During flight, each defecation was recorded and, except for the first experiment, every dropping on the floor of the test section was marked with a numbered adhesive label. Each flight lasted $12 \mathrm{hr}$. During flights, ambient temperature varied between 16 and $23^{\circ} \mathrm{C}$, humidity between 5 and $15 \mathrm{mg} \mathrm{L}^{-1}$, and air density between 1.20 and $1.23 \mathrm{~kg} \mathrm{~m}^{-3}$. Presumably, these conditions did not induce heat stress nor dehydration stress in the flying bird (Kvist et al. 1998). The morning following a flight session, all droppings were collected and pooled over flight intervals $0-2 \mathrm{hr},>2-4$ $\mathrm{hr},>4-6 \mathrm{hr}$ and $>6-12 \mathrm{hr}$. They were then oven dried at $70^{\circ} \mathrm{C}$ to constant mass, stored in a freezer, and later analyzed for organic nitrogen content using the Kjeldahl method.

\section{RECOVERY}

Immediately following the 12-hr flight session, the bird was given access to a bowl of water for 10 min while we recorded whether and how much the bird drank. Subsequently, the bird was placed in a $22 \mathrm{~L}$ metabolic chamber at $26.5^{\circ} \mathrm{C}$, where it stayed for the remaining
$60 \mathrm{hr}$ of the three-day trial, with free access to water. It had access to food (mealworms) during the last 48 $\mathrm{hr}$, and then only during the daylight period. Over these $48 \mathrm{hr}$, the bird regained the mass lost during the flight session and the night of rest following the flight. During the $12 \mathrm{hr}$ of rest and the $48 \mathrm{hr}$ of recovery, body mass, food consumption, excreta production, and oxygen consumption were monitored (for further details see Lindström et al. 1999). From data on food consumption, energy expenditure, and excreta production during the $48 \mathrm{hr}$ of recovery, we estimated the energy density and protein content of the mass increase.

\section{CALCULATIONS ON COMPOSITION OF BODY STORES}

The loss of protein during flight was calculated assuming $6.25 \mathrm{~g}$ protein per $\mathrm{g}$ nitrogen in the excreta (Blaxter 1989). The energy assimilation efficiency during recovery, $Q$, was calculated on a daily basis as

$$
Q=(G-F) / G
$$

where $G$ is the daily energy intake $\left(\mathrm{kJ} \mathrm{day}^{-1}\right.$; daily intake of mealworms [g] times the average energy density of mealworms $\left[\mathrm{kJ} \mathrm{g}^{-1}\right]$ ) and $F$ is daily excreta energy output $\left(\mathrm{kJ} \mathrm{day}^{-1}\right.$; dry mass of excreta [g] times the average energy density of excreta $\left.\left[\mathrm{kJ} \mathrm{g}^{-1}\right]\right)$. The net energy intake over the 48-hr recovery period $\left(I_{48}\right.$, $\mathrm{kJ}^{-1}$ ) was calculated as the total energy intake of mealworms during the recovery period times $Q$. The energy density of the stored tissue $\left(\alpha_{48}, \mathrm{~kJ} \mathrm{~g}^{-1}\right)$ was subsequently calculated as

$$
\alpha_{48}=\left(I_{48}-E_{48}\right) / \Delta m_{48}
$$

where $E_{48}$ is energy expenditure (kJ; using $19.8 \mathrm{~kJ} \mathrm{~L}^{-1}$ $\mathrm{O}_{2}$, assuming catabolism of fat and protein; Gessaman and Nagy 1988), and $\Delta m_{48}$ is the body mass change (g), during the $48-\mathrm{hr}$ recovery period. The energy density of the stored tissue is $38.1 \mathrm{~kJ} \mathrm{~g}^{-1}$ when consisting 
TABLE 1. Body mass changes for a Thrush Nightingale over seven 12-hr day-time flights in a wind tunnel and over the 12-hr night directly following each flight. For the subsequent $48 \mathrm{hr}$ of recovery in which the bird was provided with food, energy intake $\left(I_{48}\right)$, energy expenditure $\left(E_{48}\right)$, and changes in body mass $\left(\Delta m_{48}\right)$ are presented, allowing calculation of energy density $\left(\alpha_{48}\right)$ and composition of the deposited tissue.

\begin{tabular}{|c|c|c|c|c|c|c|c|c|c|c|c|}
\hline \multirow[b]{4}{*}{ Trial } & & & & & \multirow{2}{*}{\multicolumn{3}{|c|}{ Body mass change $(\mathrm{g})$}} & \multirow{2}{*}{\multicolumn{2}{|c|}{ Energy (kJ) }} & \multicolumn{2}{|c|}{$\begin{array}{l}\text { Body tissue } \\
\text { composition }\end{array}$} \\
\hline & \multirow{2}{*}{\multicolumn{2}{|c|}{ Date }} & & & & & & & & \multirow{3}{*}{$\begin{array}{c}\text { Energy } \\
\text { density } \\
(\mathrm{kJ} \\
\left.\mathrm{g}^{-1}\right)\end{array}$} & \multirow{3}{*}{$\begin{array}{l}\text { Protein } \\
\text { content } \\
(\%)\end{array}$} \\
\hline & & & \multicolumn{2}{|c|}{ Body mass (g) } & $12 \mathrm{hr}$ & $12 \mathrm{hr}$ & $48 \mathrm{hr}$ & Net & & & \\
\hline & Start & End & Start & End & flight & night & recovery & intake & Expenditure & & \\
\hline 1 & 18-Sep & 21-Sep & 28.00 & 27.71 & -4.19 & -1.08 & 4.98 & 209.6 & 101.5 & 21.7 & 11.5 \\
\hline 2 & 2-Oct & 5-Oct & 26.66 & 27.00 & -3.93 & -0.86 & 5.13 & 210.7 & 103.2 & 21.0 & 12.1 \\
\hline 3 & 9-Oct & $12-$ Oct & 27.00 & 27.05 & -3.50 & -0.46 & 4.01 & 187.6 & 99.2 & 22.1 & 11.3 \\
\hline 4 & $16-$ Oct & 19-Oct & 28.12 & 29.08 & -3.81 & -0.80 & 5.57 & 218.5 & 105.8 & 20.2 & 12.6 \\
\hline 5 & 23-Oct & 26-Oct & 28.97 & 29.71 & -3.83 & -0.51 & 5.08 & 210.2 & 103.4 & 21.0 & 12.0 \\
\hline 6 & 30-Oct & 2-Nov & 27.70 & 29.86 & -3.54 & -0.30 & 6.00 & 236.6 & 102.7 & 22.3 & 11.1 \\
\hline 7 & 7-Nov & 10-Nov & 28.27 & 30.65 & -3.95 & -0.33 & 6.66 & 263.3 & 109.8 & 23.0 & 10.6 \\
\hline Average & & & 27.82 & 28.72 & -3.82 & -0.67 & 5.35 & 219.5 & 103.7 & 21.6 & 11.6 \\
\hline
\end{tabular}

of only fat, stored in the adipose tissue (Johnston 1970) and $5.4 \mathrm{~kJ} \mathrm{~g}^{-1}$ when consisting of protein (assuming $77 \%$ associated water; Blaxter 1989).

Except for the first of the seven recovery periods, nitrogen balances also were determined over the 48-hr recovery phase, giving us another estimate of the proportion of protein deposited during recovery from a migratory flight. Organic nitrogen contents of food samples and samples of the excreta produced over the $48 \mathrm{hr}$ of recovery were measured by Kjeldahl's method. The nitrogen content of the mealworms was on average $86.5 \pm 4.3 \mathrm{mg} \mathrm{N} \mathrm{g}^{-1}$ dry mass (range 80.3 91.6, $n=8$ ). The nitrogen content of the excreta was on average $202.5 \pm 5.7 \mathrm{mg} \mathrm{N} \mathrm{g}^{-1}$ dry mass (range $189-209, n=12$ ). These estimates, together with estimates of food consumption and excreta production during the recovery period, allowed for the calculation of daily nitrogen intake, nitrogen excretion and, thus, nitrogen retention. Protein content of the restored tissue was calculated from nitrogen content using $6.25 \mathrm{~g}$ protein per g nitrogen (Blaxter 1989). Statistics were carried out using SYSTAT (Wilkinson 1992). Values presented are means $\pm S D$.

\section{CALCULATIONS ON POWER REQUIREMENT FOR FLIGHT}

The energy balance during each three-day trial is summarized as follows:

$$
I_{48}=E_{60}+\alpha_{d} \Delta m_{d}+\beta \mathrm{t}_{f} / 1,000
$$

where $I_{48}$ is the total net energy intake $(\mathrm{kJ})$ and $E_{60}$ the total energy expenditure $(\mathrm{kJ})$ during the complete twoand-a-half day $(60 \mathrm{hr})$ recovery period following flight, $\Delta m_{d}$ is the mass change over the whole trial (i.e., from onset of flight to end of recovery [g]), $\alpha_{d}$ is the energy density of $\Delta m_{d}\left(\mathrm{~kJ} \mathrm{~g} \mathrm{~g}^{-1}\right), t_{f}$ is the flight time in the wind tunnel (sec), and $\beta$ is the power requirement for flight (Watt). In this equation, $I_{48}, E_{60}$, and $\Delta m_{d}$ are contaminated by error, whereas $t_{f}$ is not. In the estimation of $\alpha_{d}$ and $\beta$, the various error terms were taken into account using a covariance analysis of linear structural models (CALIS, SAS Institute Inc. 1996).

\section{RESULTS}

\section{FLIGHTS}

The repeated long flights of this Thrush Nightingale are unprecedented in wind-tunnel studies of birds. Important reasons for the good performance of our experimental bird are probably related to (1) the high quality of the wind tunnel, with very low turbulence levels (Pennycuick et al. 1997), (2) the migratory bird being highly motivated through its endogenous drive for making long flights during this autumn migratory season, and (3) the bird being able to fly relatively unrestrained in a large test section. Up to 23 December 1995 , the bird flew a total of $176 \mathrm{hr}$ during trials and training flights and traveled a total air distance of 6,300 $\mathrm{km}$. Hence, for the first time it was possible to study a bird carrying out the equivalent of a full migration.

Because the flight mode of a free-flying migrating Thrush Nightingale is not known, we cannot be sure that our bird flew in a representative way. During the first hour of flight, the bird sometimes moved around in the test section and made sudden movements. On some occasions, the bird then ended in the safety net in the rear of the test section, but flight was not interrupted for more than $15 \mathrm{sec}$. However, despite these small irregularities, there are good reasons to believe that overall the wind-tunnel flights well represented what is happening in free-flying migrating Thrush Nightingales. Apart from the short interruptions during the first hour reported above, flight was stable and seemingly relaxed (Pennycuick et al. 1996). The very long flights (up to $16 \mathrm{hr}$ ), all stopped at our initiative and with the bird showing no signs of fatigue, would not have been possible if the bird flew in an unnatural way.

\section{COMPOSITION OF BODY STORES}

The body mass at the start of the flights varied between 26.7 and $29.0 \mathrm{~g}$ (Table 1). During the flights, the bird lost on average $3.8 \mathrm{~g}$, corresponding to $13.7 \%$ of the starting mass (range 12.8-15.0). In all cases the bird retained visible subcutaneous fat stores and stayed well 

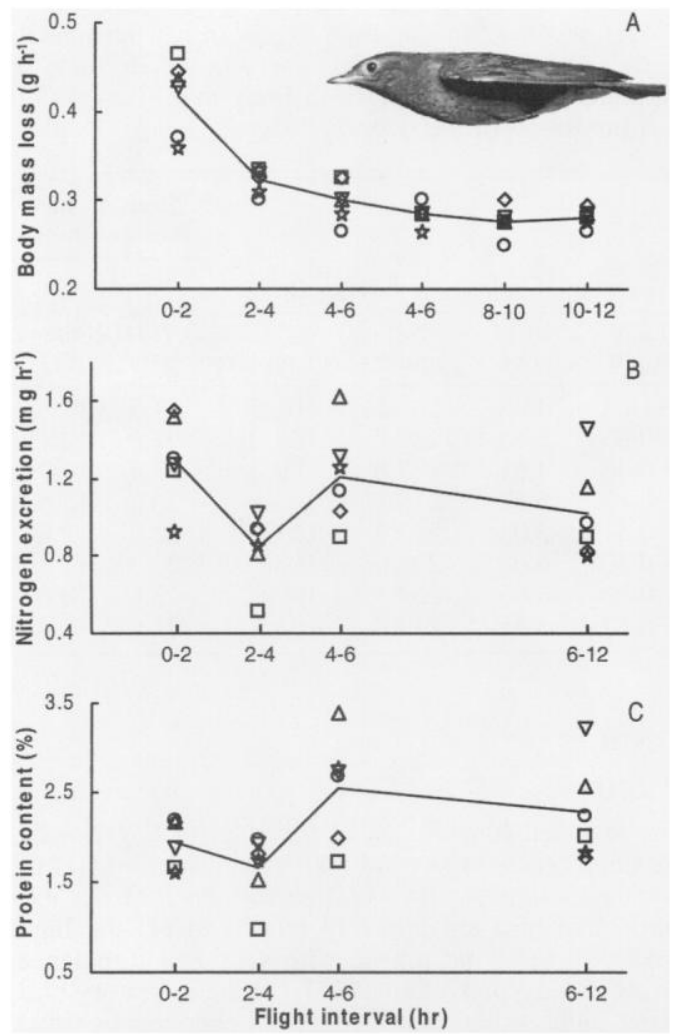

FIGURE 2. Mass loss rate (A), excretory nitrogen loss (B), and proportion of protein of the catabolized tissue (C) during six 12-hr flight trials in a wind tunnel with a Thrush Nightingale. For each trial a different symbol is used. The lines connect the averages per flight interval.

above the assumed lean body mass of $22 \mathrm{~g}$. The mass loss rate varied significantly over the flight period, being approximately $50 \%$ higher during the first $2 \mathrm{hr}$ of flight than during the last $6 \mathrm{hr}$ (repeated measures oneway ANOVA, $F_{5.25}=59.1, P<0.001$, Fig. 2 A). This may have been due to (1) a decrease in flight power with a decrease in body mass (Pennycuick 1975), (2) a proportionally high catabolism of less energy dense fuels (glycogen or protein) during the first part of the flight (Rothe et al. 1987), (3) an initial high voluntary water loss to reduce mass and flight costs (Klaassen 1995), and (4) an emptying of the digestive tract and cloaca early in flight.

The rate of nitrogen loss also varied significantly with flight time, being lowest in the 2-4-hr interval $\left(F_{3,15}=6.7, P=0.004\right.$, Fig. 2B). From the data on mass loss rate and nitrogen excretion, the average proportion of protein in the tissue catabolized during flight was estimated at $2.1 \pm 0.3 \%$, but it varied significantly between flight intervals $\left(F_{3,15}=6.2, P=0.006\right.$, Fig. 2C). Dehydration during flight would make our estimate too low. However, the bird did not drink to any large extent after the flights $(0-0.21 \mathrm{~g})$.

During the 48-hr recovery phase, the bird increased in mass with on average $5.35 \mathrm{~g}$ (Table 1). The assimilation efficiency when eating mealworms was 0.791 \pm 0.009 . From the data of body mass change, net energy intake, and energy expenditure, the energy density of the stored tissue was estimated to be on average $21.6 \mathrm{~kJ} \mathrm{~g}^{-1}$ (Table 1). Assuming that the restored tissues consist of protein (associated with $77 \%$ water; Blaxter 1989) and fat exclusively, it indicates a protein content of the body stores of $11.6 \%$.

Glycogen stores in migrating birds are generally thought to be small (Berthold 1993). The highest values reported are those of Marsh (1983), amounting to approximately $0.5 \%$ of total body mass. If the Thrush Nightingale catabolized a comparable amount of glycogen during flight, and restored all glycogen during the recovery period, glycogen may on average have comprised $2.7 \%$ of the $5.35 \mathrm{~g}$ body mass increase. Assuming that each gram of glycogen is associated with approximately $3 \mathrm{~g}$ of water, the energy density of this store is $4 \mathrm{~kJ} \mathrm{~g}^{-1}$ (Blaxter 1989) and its deposition would lower our estimate of protein content from 11.6 to $9.4 \%$.

The nitrogen balance over the recovery period suggested a protein content of $16.8 \%$ of the body stores (Table 2). Because excreted ammonia could have been lost when drying the excreta (Preest and Beuchat 1997), and therefore nitrogen excretion underestimated, we measured the ammonia content in a number of droppings from Thrush Nightingales on the same diet

TABLE 2. Nitrogen balance of a Thrush Nightingale during the 48-hr recovery period following a migratory flight in a wind tunnel. Nitrogen balance and body mass changes over the recovery period $\left(\Delta m_{48}\right)$ allow for the calculation of protein content of the deposited tissue.

\begin{tabular}{|c|c|c|c|c|c|}
\hline \multirow[b]{2}{*}{ Trial } & \multicolumn{3}{|c|}{ Organic nitrogen $(\mathrm{mg})$} & \multirow{2}{*}{$\begin{array}{l}\text { Body mass } \\
\text { change } 48-\mathrm{hr} \\
\text { recovery }(\mathrm{g})\end{array}$} & \multirow{2}{*}{$\begin{array}{l}\text { Body tissue } \\
\text { protein content } \\
(\%)\end{array}$} \\
\hline & Intake & Excreted & Retained & & \\
\hline 2 & 925.4 & 772.4 & 153.0 & 5.13 & 18.6 \\
\hline 3 & 823.9 & 677.3 & 146.6 & 4.01 & 22.9 \\
\hline 4 & 959.3 & 820.7 & 138.6 & 5.57 & 15.6 \\
\hline 5 & 920.1 & 820.8 & 99.3 & 5.08 & 12.2 \\
\hline 6 & 962.1 & 787.2 & 174.9 & 6.00 & 18.2 \\
\hline 7 & $1,028.6$ & 889.1 & 139.6 & 6.66 & 13.1 \\
\hline Average & 936.6 & 794.6 & 142.0 & 5.41 & 16.8 \\
\hline
\end{tabular}


TABLE 3. Body mass change $\left(\Delta m_{d}\right)$, net energy intake $\left(I_{48}\right)$, recovery energy expenditure $\left(E_{60}\right)$, and flight duration $\left(t_{f}\right)$ for a Thrush Nightingale over seven 3-day experimental trials including an initial 12-hr day-time flight, allowing calculation of the power requirement for migratory flight using eq. 3 .

\begin{tabular}{ccccc}
\hline \hline & \multicolumn{4}{c}{$\begin{array}{c}\text { Recovery } \\
\text { energy }\end{array}$} \\
Trial & $\begin{array}{c}\text { Flight } \\
\text { Body mass } \\
\text { change (g) }\end{array}$ & $\begin{array}{c}\text { Net energy expenditure } \\
\text { intake (kJ) }\end{array}$ & $\begin{array}{c}\text { duration } \\
\text { (kr : min) }\end{array}$ \\
\hline 1 & -0.29 & 209.6 & 119.1 & $12: 08$ \\
2 & 0.34 & 210.7 & 117.8 & $12: 00$ \\
3 & 0.05 & 187.6 & 113.4 & $12: 00$ \\
4 & 0.96 & 218.5 & 120.9 & $12: 00$ \\
5 & 0.74 & 210.2 & 118.4 & $11: 59$ \\
6 & 2.16 & 236.6 & 116.8 & $12: 00$ \\
7 & 2.38 & 263.3 & 125.2 & $12: 00$ \\
\hline
\end{tabular}

in a separate experiment by immediately solving droppings in boric acid and analyzing the $\mathrm{NH}_{4}{ }^{+}$content by a colorimetric method according to Verdouw et al. (1978). The ammonia content of the dry excreta was estimated at $1.77 \pm 3.22 \mathrm{mg} \mathrm{N} \mathrm{g}^{-1}$, which means that approximately $1 \%$ of the total $\mathrm{N}$ in the excreta is in the form of ammonia. Taking the loss of ammonia during the drying process into account, our nitrogen balance estimate of protein content in the restored tissue is reduced to $15.8 \%$. The nitrogen loss in the form of ammonia had virtually no effect on either the protein content estimates from nitrogen excretion during flight or the energy balance during recovery.

However, it is well documented that in nitrogen balance studies of animals, nitrogen losses are often underestimated when protein is catabolized rather than stored, and nitrogen retention is overestimated during periods of protein storing (Duncan 1966, Robbins 1981). Applying this finding to our study, protein loss during flight would have been underestimated, and the protein proportion of stored fuel would have been overestimated. This would make the values of $2.1 \%$ and $15.8 \%$ converge towards the energy budget estimate of $11.6 \%$ dry protein. We suggest that the dry protein proportion of the stores of our Thrush Nightingale was around $10 \%$. If accounting for the $77 \%$ water that is associated with protein (Blaxter 1989), the (wet) protein content of body stores was about $43 \%$. In terms of catabolic energy yield (assuming stores to consist of wet protein and fat exclusively), the contribution of protein is $10 \%$. These figures are within previous estimates for birds (Jenni and Jenni-Eiermann 1998). Clearly, body stores for migration partly consist of protein and there is a loss of protein during migratory flight.

\section{POWER REQUIREMENT FOR FLIGHT}

From the energy balance data (Table 3), the mean ( \pm SE) power requirement for flight in the Thrush Nightingale was estimated at $1.91 \pm 0.07$ Watts and the mean $\left( \pm\right.$ SE) energy density of the reserve tissue $\left(\alpha_{d}\right)$ at $13.3 \pm 11.6 \mathrm{~kJ} \mathrm{~g} \mathrm{~g}^{-1}$ using eq. 3 . The design of the experiment was chosen such that body mass at the start of the 3-day trial was almost identical to the body mass at the end of the trial. Variation in $\Delta m_{d}$ was therefore small, causing the large variation in $\alpha_{d \cdot} \alpha_{d}$ was not significantly different from the average $\alpha_{48}$ of $21.6 \mathrm{~kJ}$ $\mathrm{g}^{-1}$ estimated from the recovery energy budget (Table $1 ; t$-test, $t_{6}=0.7, P=0.53$ ). Setting $\alpha_{d}$ in eq. 3 to $21.6 \mathrm{~kJ} \mathrm{~g}^{-1}$ results only in a minor change in the estimated flight costs to 1.86 Watts. Thus, with our data the calculation of the power requirements for flight are rather indifferent to $\alpha_{d}$. Although the seven trials were conducted with great care and accuracy, assuming systematic errors in the estimation of $I_{48}$ and $E_{60}$ of maximally $\pm 5 \%$ would still result in power estimates in a rather narrow range of 1.54-2.27 Watts.

\section{DISCUSSION}

\section{PROTEIN CATABOLISM DURING MIGRATORY FLIGHT}

Although we present data on one individual only, our study of a Thrush Nightingale migrating in captivity is the first to present direct evidence of protein loss during migratory flight. The involvement of protein during migratory flight was previously suggested by various studies. In birds trapped during active nighttime migration, and in homing pigeons (Columba liv$i a)$, elevated uric acid levels in the blood indicated the use of protein during flight (Jenni-Eiermann and Jenni 1991, Schwilch et al. 1996). In starving Thrush Nightingales, 5-9\% of the body mass loss was dry protein (Klaassen et al. 1997). Moreover, it has been shown repeatedly that protein is deposited prior to migratory flights (Lindström and Piersma 1993, Klaassen and Biebach 1994), amounting to $6 \%$ in Thrush Nightingale (Klaassen et al. 1997). Also, protein loss during endurance exercise in humans and other mammals is an established phenomenon (Dohm 1986, Goldspink 1991).

In the literature there are six possible explanations for protein loss during migratory flights: (1) protein turnover always occurs and a protein loss is due to an inefficiency in this process (Dohm 1986), (2) glucose availability is important for proper functioning of the nervous system and protein is the source for gluconeogenesis (Dohm 1986), (3) protein is a source of citric acid cycle intermediates (Dohm 1986), (4) protein catabolism plays a role in avoiding dehydration as protein results in a higher metabolic water yield per unit energy than lipid catabolism (Klaassen 1996, Klaassen et al. 1999), (5) protein loss is a result of an adaptive reduction in the size of the flight muscles (Pennycuick 1975), and (6) protein loss is a result of an adaptive reduction in the size of the digestive system (Biebach 1998, Piersma and Gill 1998, Lindström et al. 1999).

A seemingly unexplored aspect of protein breakdown during flight and a potential seventh explanation for this phenomenon, relates to the fact that uric acid, the main by-product of protein catabolism in birds, is an antioxidant (Keaney and Frei 1994). Antioxidants detoxify free radicals, harmful molecules produced when aerobic cells consume oxygen. There is normally a higher production of free radicals than there are antioxidants, a state known as "oxidative stress." Oxidative stress increases with amount of muscle work (Kehrer and Smith 1994). Whatever the main cause of 


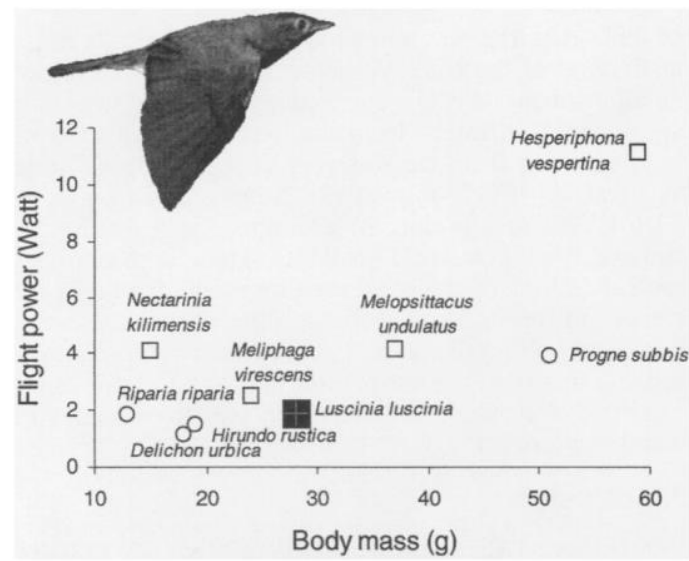

FIGURE 3. Measurements of power requirements of flight (Watt) in relation to body mass (g) for small birds in the range $10-60 \mathrm{~g}$. Open symbols: data from the literature listed in Norberg (1996). Data on birds flying in confined spaces, possibly influencing the flow pattern of the air around the wings are excluded from this data set. Flight power estimates from mass loss data are not included, as the many assumptions for reliable calculations of flight power from mass-loss data (Kvist et al. 1998) were not met. Black square: this study. Squares: non-aerial feeders. Circles: aerial feeders.

protein breakdown during flight, the accompanying high levels of uric acid in birds during flight (JenniEiermann and Jenni 1991) may help to defend the body against oxidative stress.

The seven explanations for protein loss listed above are clearly not mutually exclusive and several or all of them may act in concert. Whereas the proximate physiological causes put forward (\# 1-3) may well be valid, we would like to stress the potential importance of an adaptive physiological flexibility when explaining protein loss in migrating birds. It may be of crucial importance to birds to optimize the use of energy and time during migration (Alerstam and Lindström 1990). Reversible changes in organ size could be one important component of such an optimization process (Piersma and Lindström 1997, Piersma 1998). Yet, the cause and exact origin of protein loss in migrating birds remains to be determined.

\section{POWER REQUIREMENT FOR MIGRATORY FLIGHT}

Few reliable flight power measurements are available for comparison with our estimate for the Thrush Nightingale and those that do exist all deal with nonmigrating birds (Masman and Klaassen 1987, Norberg 1996). Compared to birds of similar mass and wing span, the flight power of the Thrush Nightingale is as low as for swallows (Hirundinidae; Fig. 3). This is surprising, because the aspect ratio, a measure of wing shape, of 5.3 of our Thrush Nightingale (Pennycuick et al. 1996) is much lower than that of swallows (7.2-7.7; C. J. Pennycuick and S. Kirkpatrick, pers. comm.). A high aspect ratio typically results in a low flight power and is characteristic for aerial feeders that spend a large part of the day on the wing (Norberg 1996). Most likely, it is the nature of the flight during the various published experiments that explains why our Thrush Nightingale ends up amid the low cost aerial feeders. All studies depicted in Figure 3 measured birds that were either flying during short to very short periods of time, from a couple of seconds to a couple of minutes, often in combination with foraging. The question is whether our result is of general applicability and whether power requirements for migratory flight are lower than previously thought. If so, birds would be capable of migrating longer distances on their body stores.

Aerodynamic models are often used to calculate the flight costs for migratory birds. The model by Pennycuick (1989) is the most popular model used for this purpose. Using the default values recommended by Pennycuick (1989), the model predicts a flight power of 2.38 Watts for a bird with the mass and wing shape of our Thrush Nightingale flying at $10 \mathrm{~m} \mathrm{sec}^{-1}$. This is $25 \%$ higher than our estimate of 1.91 Watts. However, with the recent modifications in body drag coefficient, as proposed by Pennycuick et al. (1996), the calculated power would be $30 \%$ lower than our estimate. Thus, flight costs for migrants are currently predicted to be even lower than we measured in this study. Yet, despite the recent modification, the predictive value of Pennycuick's and other aerodynamic models is still under scrutiny, both with respect to their predictions of optimal flight speeds and how flight power changes with flight speed (Kvist et al. 1998). The discrepancy between our results and the model predictions should urge us to continue amassing empirical flight data and to view the results predicted by current aerodynamic models with some caution.

L. Jenni, S. Jenni-Eiermann, Y. Le Maho, T. Piersma, and B. Pinshow gave valuable comments on earlier drafts of the manuscript. R. Moss drew our attention to the difficulties seemingly inherent to nitrogen balance studies. The wind-tunnel facilities were financed through grants from Knut and Alice Wallenberg Foundation (to T. Alerstam), the Swedish Council for Planning and Co-ordination of Research (FRN), and the Swedish Natural Science Research Council (NFR, to TA and ÅL). This study was supported by grants from NFR (to AL) and the Swedish Institute (to MK). To these people and institutions we are most grateful. This is publication No. 2605, Netherlands Institute of Ecology, Centre for Limnology, Nieuwersluis.

\section{LITERATURE CITED}

AlerstaM, T., AND Å. LiNDSTRÖM. 1990. Optimal bird migration: the relative importance of time, energy and safety, p. 331-351. In E. Gwinner [ed.], Bird migration: the physiology and ecophysiology. Springer-Verlag, Berlin.

BERTHOLD, P. 1993. Control of bird migration. Chapman and Hall, London.

BIEBACH, H. 1998. Phenotypic organ flexibility in Garden Warblers Sylvia borin during long-distance migration. J. Avian Biol. 29:529-535. 
BlaXter, K. L. 1989. Energy metabolism in animals and man. Cambridge Univ. Press, Cambridge.

CRAMP, S. [ED.]. 1985, Handbook of the birds of Europe, the Middle East and North Africa. Vol. 5. Oxford Univ. Press, Oxford.

DoHM, G. L. 1986. Protein as fuel for endurance exercise. Exercise Sport Sci. Rev. 14:143-173.

Duncan, A. A. 1966. The balance trial and its limitations, p. 51-80. In J. T. Abrams [ED.], Recent advances in animal nutrition. Churchill, London.

Gessaman, J. A., AND K. A. Nagy. 1988. Energy metabolism: errors in gas-exchange conversion factors. Physiol. Zool. 61:507-513.

GolDSPINK, D. F. 1991. Exercise related changes in protein turnover in mammalian striated muscle. J. Exp. Biol. 160:127-148.

Jenni, L., AND S. JENni-Eiermann. 1998. Fuel supply and metabolic constraints in migrating birds. J. Avian Biol. 29:521-528.

JENNI-EIERMANN, S., AND L. JENNI. 1991. Metabolic responses to flight and fasting in night migrating passerines. J. Comp. Physiol B 161:465-474.

JoHNSTON, D. W. 1970. Caloric density of avian adipose tissue. Comp. Biochem. Physiol. 34:827832.

KeANEY, J. F., JR., AND B. Frei. 1994. Antioxidant protection of low-density lipoprotein and its role in the prevention of atherosclerotic vascular disease, p. 303-351. In B. Frei [ED.], Natural antioxidants in human health and disease. Academic Press, San Diego, CA.

KeHRER, J. P., AND C. V. SMITH. 1994. Free radicals in biology: sources, reactivities, and roles in the etiology of human diseases, p. 25-62. In B. Frei [ED.], Natural antioxidants in human health and disease. Academic Press, San Diego, CA.

KLAASSEN, M. 1995. Water and energy limitations on flight range. Auk 112:260-262.

KlAASSEN, M. 1996. Metabolic constraints on longdistance migration in birds. J. Exp. Biol. 199:5764.

KlaASSEN, M., AND H. BIEBACH. 1994. Energetics of fattening and starvation in the long-distance migratory Garden Warbler, Sylvia borin, during the migratory phase. J. Comp. Physiol. B 164:362371.

KlaAassEn, M., A. KVIST, AND Å. Lindström. 1999. How body water and fuel stores affect long distance flight in migrating birds. Proc. Int. Ornithol. Congr. 22:1450-1467.

KlaASSEN, M., Å. LindSTRÖM, AND R. ZiJlstRa. 1997. Composition of fuel stores and digestive limitations to fuel deposition rate in the long-distance migratory Thrush Nightingale Luscinia luscinia. Physiol. Zool. 70:125-133.

KVIST, A., M. KlaASSEN, AND Å. LindSTRÖM. 1998. Energy expenditure in relation to flight speed: what is the power of mass loss rate estimates? J. Avian Biol. 29:485-498.

LindströM, A., M. KlaAsSEn, AND A. Kvist. 1999. Variation in energy intake and basal metabolic rate of a bird migrating in a wind-tunnel. Func. Ecol. 13:352-359.
LindströM, Å., AND T. PIERSMA. 1993. Mass changes in migrating birds: the evidence for fat and protein storage re-examined. Ibis 135:70-78.

Marsh, R. L. 1983. Adaptations of the Gray Catbird Dumetella carolinensis to long distance migration: energy stores and substrate concentrations in plasma. Auk 100:170-179.

Masman, D., AND M. KlaAsSEn. 1987. Energy expenditure during free flight in trained and free-living Eurasian Kestrels (Falco tinnunculus). Auk 104: 603-616.

NORBERG, U. 1996. Energetics of flight, p. 199-249. In C. Carey [ED.], Avian energetics and nutritional ecology. Chapman and Hall, New York.

Odum, E. P., D. T. Rogers, AND D. L. Hicks. 1964. Homeostasis of the nonfat components of migrating birds. Science 143:1037-1039.

PENNYCUICK, C. J. 1975. Mechanics of flight, p. 1-75. In D. S. Farner and J. R. King [ED.], Avian biology. Vol. 5. Academic Press, New York.

PenNyCuick, C. J. 1989. Bird flight performance. Oxford Univ. Press, Oxford.

PENNYCUICK, C. J. 1998. Towards an optimal strategy for bird flight research. J. Avian Biol. 29:449457.

Pennycuick, C. J., T. Alerstam, And A. Hedenström. 1997. A new low-turbulence wind tunnel for bird flight experiments at Lund University, Sweden. J. Exp. Biol. 200:1441-1449.

PennyCuick, C. J., M. KlaAssen, A. Kvist, and Å. LINDSTRÖM. 1996. Wingbeat frequency and the body drag anomaly: wind-tunnel observations on a Thrush Nightingale (Luscinia luscinia) and a Teal (Anas crecca). J. Exp. Biol. 199:2757-2765.

Piersma, T. 1998. Phenotypic flexibility during migration: optimization of organ size contingent on the risks and rewards of fueling and flight? J. Avian Biol. 29:511-520.

PIERSMa, T., AND R. E. Gill JR. 1998. Guts don't fly: small digestive organs in obese Bar-tailed Godwits. Auk 115:196-203.

Piersma, T., AND A. LindSTRÖM. 1997. Rapid reversible changes in organ size as a component of adaptive behaviour. Trends Ecol. Evol. 12:134-138.

Preest, M. R., AND C. A. Beuchat. 1997. Ammonia excretion by hummingbirds. Nature 386:561-562.

RobBINS, C. T. 1981. Estimation of the relative protein cost of reproduction in birds. Condor 83:177-179.

Rothe, H-J., W. Biesel, AND W. Nachtigall. 1987. Pigeon flight in a wind tunnel. II. Gas exchange and power requirements. J. Comp. Physiol. B 157: 99-109.

SAS INSTITUTE INC. 1996. SAS/STAT user's guide, version 6. Vol. 1. SAS Institute Inc., Cary, NC.

SChwILCH, R., L. JENNI, AND S. JENNI-EIERMANN. 1996. Metabolic responses of homing pigeons to flight and subsequent recovery. J. Comp. Physiol. B 166:77-87.

Verdouw, H., C. J. A. Van Echteld, and E. M. J. DEKKERS. 1978. Ammonia determination based on inophenol formation with sodium salicylate. Water Res. 12:399-402.

WILKINSON, L. 1992. SYSTAT for Windows 5. SYSTAT Inc., Evanston, IL. 
http://www.jstor.org

\section{LINKED CITATIONS \\ - Page 1 of 1 -}

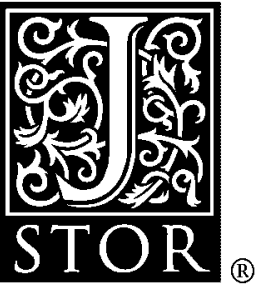

You have printed the following article:

Flight Costs and Fuel Composition of a Bird Migrating in a Wind Tunnel

Marcel Klaassen; Anders Kvist; Åke Lindström

The Condor, Vol. 102, No. 2. (May, 2000), pp. 444-451.

Stable URL:

http://links.jstor.org/sici?sici=0010-5422\%28200005\%29102\%3A2\%3C444\%3AFCAFCO $\% 3 \mathrm{E} 2.0 . \mathrm{CO} \% 3 \mathrm{~B} 2-\% 23$

This article references the following linked citations. If you are trying to access articles from an off-campus location, you may be required to first logon via your library web site to access JSTOR. Please visit your library's website or contact a librarian to learn about options for remote access to JSTOR.

\section{Literature Cited}

\section{Homeostasis of the Nonfat Components of Migrating Birds}

Eugene P. Odum; David T. Rogers; David L. Hicks

Science, New Series, Vol. 143, No. 3610. (Mar. 6, 1964), pp. 1037-1039.

Stable URL:

http://links.jstor.org/sici?sici=0036-8075\%2819640306\%293\%3A143\%3A3610\%3C1037\%3AHOTNCO\%3E2.0.CO\%3B2-K

\section{Estimation of the Relative Protein Cost of Reproduction in Birds}

Charles T. Robbins

The Condor, Vol. 83, No. 2. (May, 1981), pp. 177-179.

Stable URL:

http://links.jstor.org/sici?sici=0010-5422\%28198105\%2983\%3A2\%3C177\%3AEOTRPC\%3E2.0.CO\%3B2-2 